\title{
BESAR RISIKO FAKTOR FISIOLOGI PADA KEJADIAN HIPERURISEMIA DI MASYARAKAT WILAYAH PUSKESMAS TLOGOSARI KULON KOTA SEMARANG
}

\section{GREAT RISK OF PHYSIOLOGY FACTORS IN HIPERURISMIC EVENTS IN COMMUNITY AREAS OF PUSKESMAS TLOGOSARI KULON SEMARANG CITY}

\author{
Ade Annisa Nuraini ${ }^{1}$, Kun Aristiati $\mathrm{S}^{2}$, Wiwik Wijaningsih ${ }^{2}$ \\ ${ }^{1}$ Mahasiswa Jurusan Gizi Politeknik Kesehatan Kemenkes Semarang \\ ${ }^{2}$ Dosen Jurusan Gizi Politeknik Kesehatan Kemenkes Semarang
}

\section{ABSTRACT}

Background : Hyperuricemia is one form of non-infectious disease caused by dietary changes with the composition of foods that contain lots of protein and fat. Factors that affect the occurrence of hyperuricemia include food intake factors, physiological factors, behavioral factors.

Objective : To determine the risk of physiological factors to hyperuricemia.

Research Method : This research used observational method with case control design in the community in the work area of Tlogosari Kulon Community Health Center Semarang. The samples of research were taken by randomly sampling technique,obtained 25 case samples and 25 control samples. Hyperuricemia data was obtained from laboratory examination data. Physiological factor data (nutritional status, waist circumference, waist circumference ratio, blood pressure, age, sex, education, employment, and family income) collected with interview using questionare to the sampelt. Bivariate analysys result using chi-square test and full multivariate analysis result using multiple logistic reggression test.

Result : The risk factor for hyperuricemia is waist circumference $>80 \mathrm{~cm}$ for women and $>90 \mathrm{~cm}$ for men at risk 3.27 times hyperuricemia compared with waist circumference $\leq 80 \mathrm{~cm}$ for women and $\leq 90 \mathrm{~cm}$ for men. $195 \% \mathrm{Cl}$ 1,18 - 12.60). Nutritional status, waist circumference ratio, blood pressure, age, sex, education, employment, and family income were not at risko to hyperuricemia.

Conclusion : The risk of physiological factors to hyperuricemia are waist circumference.

Keywords : physiological factors, hyperuricemia

\section{ABSTRAK}

Latar Belakang : Hiperurisemia merupakan salah satu bentuk Penyakit Tidak Menular yang disebabkan oleh perubahan pola makan dengan komposisi makanan yang mengandung banyak protein dan lemak. Faktor-faktor yang memengaruhi terjadinya hiperurisemia diantaranya adalah faktor asupan, faktor fisiologi, dan faktor perilaku.

Tujuan : Untuk mengetahui besar risiko faktor fisiologi terhadap kejadian hiperurisemia.

Metode : Penelitian ini menggunakan metode observasional dengan rancangan case control pada masyarakat di wilayah Puskesmas Tlogosari Kulon Kota Semarang. Pengambilan sampel dilakukan secara acak diperoleh 25 sampel kasus dan 25 sampel kontrol. Data hiperurisemia diperoleh dari data pemeriksaan labortorium. Data faktor fisiologi (status gizi, lingkar pinggang, rasio lingkar pinggang dan panggul, tekanan darah, umur, jenis kelamin, pendidikan pekerjaan, pendapatan) dengan wawancara langsung menggunakan kuesioner kepada sampel. Hasil analisis bivariate dengan menggunakan uji chi-square dan multivariate full model dengan menggunakan uji regresi logistik ganda.

Hasil : Faktor yang berisiko terhadap hiperurisemia yaitu lingkar pinggang $>80 \mathrm{~cm}$ untuk perempuan dan $>90 \mathrm{~cm}$ untuk laki-laki berisiko 3,85 kali menderita hiperurisemia dibandingan dengan lingkar pinggang $\leq 80 \mathrm{~cm}$ untuk perempuan dan $\leq 90 \mathrm{~cm}$ untuk laki-laki. $(p=0,023 ; 95 \% \mathrm{Cl} 1,18-12,60)$. Status gizi, rasio lingkar pinggang dan 
panggul, tekanan darah, umur, jenis kelamin, pendidikan pekerjaan dan pendapatan tidak berisiko terhadap hiperurisemia.

Kesimpulan : Faktor yang berisiko terhadap hiperurisemia yaitu lingkar pinggang.

Kata kunci : faktor fisiologi, hiperurisemia

\section{PENDAHULUAN}

Penyakit Tidak Menular (PTM), merupakan penyakit kronik yang tidak ditularkan dari orang ke orang. PTM mempunyai durasi yang panjang dan umumnya berkembang lambat. PTM menjadi penyebab utama kematian secara global. Berdasarkan data WHO menunjukkan bahwa dari 57 juta kematian yang terjadi di dunia pada tahun 2008, sebanyak 36 juta atau hampir dua pertiganya disebabkan oleh PTM ${ }^{1}$.

Hiperurisemia merupakan salah satu bentuk PTM yang disebabkan oleh perubahan pola makan dengan komposisi makanan yang mengandung banyak protein dan lemak. Selain itu dapat disebabkan oleh faktor genetik, berat badan berlebih, dan juga penyakit tertentu yang dapat meningkatkan kadar asam urat, seperti penyakit Diabetes Mellitus, penyakit ginjal, dan penyakit Jantung. Hiperurisemia bukan merupakan penyakit yang mematikan, tetapi jika tidak ditangani akan menimbulkan penumpukan kristal asam urat, apabila kristal asam urat berada dalam cairan sendi maka akan menyebabkan menjadi penyakit Gout Kronik, Batu Ginjal, Gagal Ginjal bahkan penyakit jantung ${ }^{2}$.

Kejadian Serum Uric Acid (SUA) terbukti mengalami peningkatan di seluruh wilayah dunia. Gout adalah penyakit musculosketal kronis (MSK) yang menimpa $1-2 \%$ populasi dunia dan telah diidentifikasi sebagai salah satu gangguan MSK utama yang berkontribusi terhadap meningkatnya beban MSK dalam studi Global Burden Diseases (GBD), Injures and Risk Factors 2010\&2013. Berdasarkan studi epidemiologi yang dimuat dalam Amercian College og Rheumatology Meeting Abstract pada tahun 2015, prevalensi hiperurisemia tertinggi ditemukan di wilayah Oceania, tepatnya di Kepulauan Marshall yaitu sebesar $85 \%$ dan prevalensi terendah sebesar $1 \%$ terdapat di Papua Nugini. Kejadian hiperurisemia di wilayah Asia relatif lebih umum terjadi. Berdasarkan studi tersebut dilaporkan bahwa kejadian hiperurisemia di Indonesia sebesar $18 \%{ }^{3}$. Untuk wilayah Kota Semarang, belum ada data pasti untuk kasus hiperurisemia. Berdasarkan laporan Dinas Kesehatan Kota Semarang ditemukan 2.914 kasus $(0,18 \%)$ arthritis gout di Kota Semarang pada tahun 2016. Angka kejadian hiperurisemia pada masyarakat yang memeriksakan kadar asam urat di
Puskesmas Tlogosari Kulon pada tahun 2015 sebanyak 54 orang dan 157 orang pada tahun 2016. Faktor risiko terjadinya asam urat dibedakan menjadi tiga yaitu faktor asupan, faktor fisiologi dan faktor perilaku. Untuk faktor asupan dibedakan menjadi dua, yaitu : asupan yang meningkatkan dan asupan yang menurunkan kadar asam urat. Asupan yang termasuk meningkatkan yaitu asupan makanan sumber purin dan fruktosa 4 ${ }^{5}$. Sedangkan asupan yang menurunkan antara lain asupan makanan sumber vitamin C, asam folat, kalsium, magnesium dan cairan ${ }^{678}$. Faktor fisiologi meliputi status gizi, lingkar pinggang, rasio lingkar pinggang dan panggul, tekanan darah, umur, jenis kelamin, pendidikan pekerjaan dan pendapatan 910 1112131214 . Faktor perilaku meliputi pengetahuan, sikap, alkohol, obat-obatan dan aktivitas fisik ${ }^{15} 1617$. Tujuan penelitian ini yaitu untuk mengetahui besar risiko faktor fisiologi pada kejadian hiperurisemia di Puskesmas Tlogosari Kulon Kota Semarang.

\section{METODE}

Penelitian ini merupakan penelitian bidang ilmu Gizi Klinik dengan jenis penelitian yaitu observasional untuk mengetahui besar risiko faktor fisiologi yang meliputi status gizi, lingkar pinggang, rasio lingkar pinggang dengan lingkar panggul, tekanan darah, umur, jenis kelamin, pendidikan pekerjaan dan pendapatan pada kejadian hiperurisemia. Rancangan penelitian yang digunakan yaitu cross sectional dengan membandingkan antara kelompok kasus dan kelompok kontrol berdasarkan status paparannya dengan perbandingan besar sampel untuk kelompok kasus dan kelompok kontrol adalah 1:1.

Populasi dalam penelitian ini adalah seluruh pengunjung rawat jalan yang berumur $\geq 20$ tahun dan memeriksakan kadar asam urat di Puskesmas Tlogosari Kota Semarang. Sampel dalam penelitian ini adalah pengunjung rawat jalan yang mempunyai kadar asam urat tinggi ( $>7 \mathrm{mg} / \mathrm{dL}$ untuk laki-laki atau $>6 \mathrm{mg} / \mathrm{dL}$ untuk perempuan) dan normal ( $<6 \mathrm{mg} / \mathrm{dL}$ untuk laki-laki atau $<5 \mathrm{mg} / \mathrm{dL}$ untuk perempuan).

Jumlah sampel penelitian diperoleh dengan perhitungan rumus untuk menghitung jumlah sampel pada kasus-kontrol tidak sepadan dengan nilai $Z \alpha=2,58 ; Z \beta ; \bar{p}=0,38 ; \bar{q}=0,62$ sehingga didapatkan besar sampel minimal 15 sampel. Pada 
penelitian ini diambil 20 sampel yang telah memenuhi minimal besar sampel diatas. Cadangan yang digunakan adalah $25 \%$ sebesar 5 sampel. Jadi total sampel yang digunakan dalam penelitian ini adalah 25 sampel kelompok kontrol dan 25 sampel kelompok kasus. Variabel penelitian ini terdiri dari variable dependen yaitu hiperurisemia sedangkan variabel independennya adalah status gizi, lingkar pinggang, rasio lingkar pinggang dan panggul, tekanan darah, umur, jenis kelamin, pendidikan pekerjaan dan pendapatan.

Data tentang identitas subyek meliputi nama, umur, jenis kelamin, pendidikan, pekerjaan, pendapatan, dan jumlah anggota keluarga diperoleh dengan wawancara menggunakan kuesioner. Data antropometri meliputi berat badan, tinggi badan, lingkar pinggang dan lingkar panggul diperoleh dengan melakukan penimbangan berat badan, pengukuran tinggi badan, lingkar pinggang dan lingkar panggul. Data pemeriksaan kadar asam urat pasien diperoleh dari data laboratorium Puskesmas Tlogosari Kulon. Data tekanan darah (sistol dan diastol) pasien diperoleh dari catatan medik.

Analisis univariat dilakukan untuk mendeskripsikan karakteristik sampel dalam bentuk proporsi, mean, median, minimum, maksimum, dan standar deviasi yaitu meliputi jenis kelamin, umur, status gizi, lingkar pinggang, rasio lingkar panggul, tekanan darah, pendidikan, pekerjaan, dan pendapatan. Analisis bivariat dengan menggunakan uji chi square dan fisher exact pada tingkat kemaknaan $p<0,05$. Analisis multivariat dilakukan untuk menganalisis pengaruh variabel bebas terhadap variabel terikat, dan seberapa besar variabel bebas berpengaruh terhadap variabel terikat yang diuji dengan uji regresi logistik ganda.

\section{HASIL DAN PEMBAHASAN}

Penelitian dilakukan di Masyarakat Wilayah Puskesmas Tlogosari Kulon Kota Semarang. Penelitian dilaksanakan selama dua bulan dimulai tanggal 2 April 2018 sampai 31 Mei 2018.

\section{A. Karakteristik Sampel}

Sampel dalam penelitian ini adalah pengunjung Puskesmas Tlogosari Kulon yang sesuai dengan kriteria sampel yang memiliki kadar asam urat tinggi dan normal. Berdasarkan pengambilan data yang dilakukan selama dua bulan didapatkan jumlah pasien yang memiliki kadar asam urat tinggi sebesar 30 orang, dan sampel yang memiliki kadar asam urat normal sebesar 53 orang. Kemudian dilakukan pengambilan sampel secara acak 25 orang untuk sampel kasus dan 25 orang untuk sampel kontrol. Distribusi karakteristik sampel dapat dilihat pada tabel 1 .

Tabel 1 Distribusi Karakteristik Sampel Hiperurisemia dan Tidak Hiperurisemia pada Masyarakat di Puskesmas tlogosari Kulon Kota Semarang Tahun 2018

\begin{tabular}{|c|c|c|c|c|}
\hline \multirow{3}{*}{ Variabel } & \multicolumn{2}{|c|}{ Kadar Asam Urat } & \multicolumn{2}{|c|}{ Mean \pm Std. Deviasi } \\
\hline & Normal & Hiperurisemi & & \\
\hline & $n(\%)$ & $n(\%)$ & Kontrol & Kasus \\
\hline Status Gizi & & & $23,08 \pm 3,34$ & $26,30 \pm 5,12$ \\
\hline Tidak Obesitas & $13(52,0 \%)$ & $7(28,0 \%)$ & & \\
\hline Obesitas & $12(48,0 \%)$ & $18(72,0 \%)$ & & \\
\hline Lingkar Pinggang & & & $84,64 \pm 10,89$ & $91,50 \pm 11,43$ \\
\hline Tidak Berisiko & $15(60,0 \%)$ & $7(28,0 \%)$ & & \\
\hline Berisiko & $10(40,0 \%)$ & $18(72,0 \%)$ & & \\
\hline RLPP & & & $0,94 \pm 0,05$ & $0,95 \pm 0,06$ \\
\hline Tidak Berisiko & $2(8,0 \%)$ & $1(4,0 \%)$ & & \\
\hline Berisiko & $23(92,0 \%)$ & $24(96,0 \%)$ & & \\
\hline Tekanan Darah & & & & \\
\hline Tidak Hipertensi & $19(76,0 \%)$ & $16(64,0 \%)$ & & \\
\hline Hipertensi & $6(24,0)$ & $9(36,0 \%)$ & & \\
\hline Umur & & & $51,12 \pm 10,79$ & $48,68 \pm 10,85$ \\
\hline$<40$ tahun & $3(12,0 \%)$ & $5(20,0 \%)$ & & \\
\hline $40-54$ tahun & $9(36,0 \%)$ & $13(52,0 \%)$ & & \\
\hline$\geq 55$ tahun & $13(52,0 \%)$ & $7(28,0 \%)$ & & \\
\hline Jenis Kelamin & & & & \\
\hline Perempuan & $13(52,0 \%)$ & $15(60,0 \%)$ & & \\
\hline Laki-laki & $12(48,0 \%)$ & $10(40,0 \%)$ & & \\
\hline Pendidikan & & & & \\
\hline$\leq S D$ & $6(24,0 \%)$ & $5(20,0 \%)$ & & \\
\hline SMP & $1(4,0 \%)$ & $3(12,0 \%)$ & & \\
\hline$\geq S M A$ & $18(72,0 \%)$ & $17(68,0 \%)$ & & \\
\hline Pekerjaan & & & & \\
\hline Pegawai & $8(32,0 \%)$ & $9(36,0 \%)$ & & \\
\hline Buruh & $7(28,0 \%)$ & $10(40,0 \%)$ & & \\
\hline Tidak Bekerja & $10(40,0 \%)$ & $6(24,0 \%)$ & & \\
\hline Pendapatan & & & $19127808 \pm 1,09$ & $19930742 \pm 1,21$ \\
\hline < Perkapita & $24(96,0 \%)$ & $22(88,0 \%)$ & & \\
\hline$\geq$ Perkapita & $1(4,0 \%)$ & $3(12,0 \%)$ & & \\
\hline
\end{tabular}

Berdasarkan hasil penelitian, pada kelompok kontrol, paling banyak sampel dengan $\geq 55$ tahun sebanyak $52,0 \%$, jenis kelamin perempuan sebanyak 52,0\%, pendidikan $\geq$ SMA sebanyak $72,0 \%$, tidak bekerja sebanyak $40,0 \%$, pendapatan kurang dari perkapita sebanyak $96,0 \%$, status gizi tidak obesitas sebesar $52,0 \%$, lingkar pinggang tidak berisiko $60,0 \%$, rasio lingkar pinggang panggul berisiko 92,0\%, dan tidak hipertensi 76,0\%. Pada kelompok kasus, paling banyak sampel dengan umur 40-54 tahun sebanyak 52,0\%, jenis kelamin perempuan sebanyak $60,0 \%$, yang memiliki pendidikan $\geq S M A 68,0 \%$, yang bekerja sebagai buruh $40,0 \%$, yang memiliki pendapatan kurang dari perkapita sebanyak $88,0 \%$, yang memiliki status gizi obesitas $72,0 \%$, yang memiliki lingkar pinggang berisiko $72,0 \%$, yang memiliki rasio lingkar pinggang panggul berisiko 96,0\%, yang tidak hipertensi sebanyak $64,0 \%$.

\section{B. Analisis Bivariat dan Multivariat}

\section{Status Gizi dengan Hiperurisemia}

Hasil analisis menggunakan chi square tidak terdapat hubungan yang signifikan antara status gizi dengan kejadian hiperurisemia dengan $p=0,083$; 
$\mathrm{OR}=2,78 ; 95 \% \mathrm{Cl}=0,86-9,01$. Penelitian ini sejalan dengan penelitian yang dilakukan di Desa Banjaranyar terhadap 52 sampel bahwa tidak ada hubungan yang signifikan antara status gizi dengan penyakit asam urat dengan $p=0,70^{18}$.

Berdasarkan analisis multivariat pada full model dengan menggunakan uji regresi logistic ganda menunjukkan tidak terdapat hubungan yang signifikan antara status gizi dengan kejadian hiperurisemia dengan $p=0,25 ; \mathrm{OR}=0,32 ; 95 \% \mathrm{Cl}=0,04-$ 2,21 . Lain halnya dengan penelitian yang dilakukan di Cina pada tahun 2012 yang menunjukkan adanya hubungan antara status gizi dengan hiperurisemia dengan $p=0,004^{19}$.

Penelitian ini tidak terdapat hubungan antara status gizi dengan hiperurisemia. Hasil tersebut dipengaruhi oleh asupan makanan yang dapat meningkatkan kadar asam urat. Orang yang memiliki status gizi obesitas tidak berarti mengkonsumi banyak asupan sumber purin, dan sebaliknya orang yang memiliki status gizi normal tidak berarti mengkonsumsi asupan sumber purin dengan jumlah sedikit.

2. Hubungan Lingkar Pinggang dengan Hiperurisemia

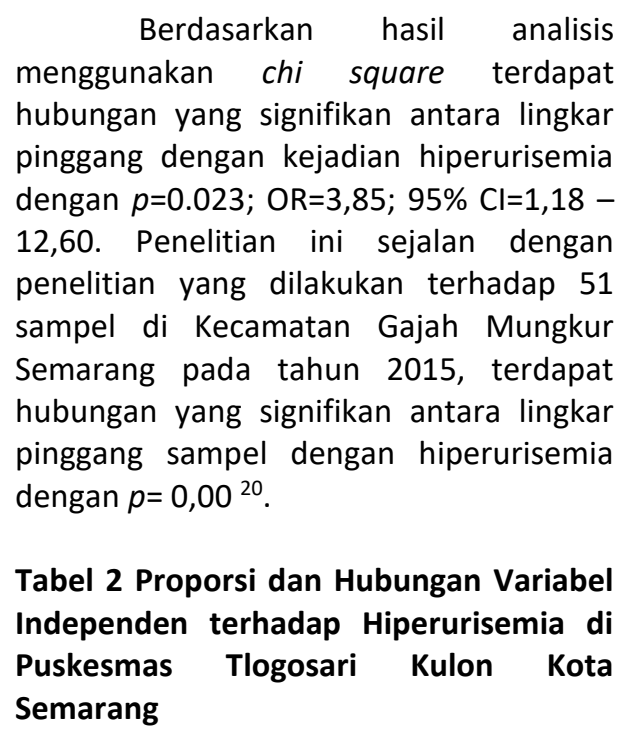

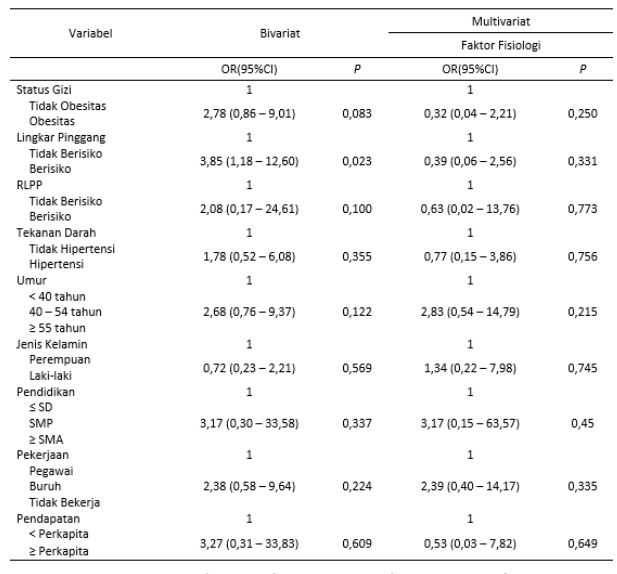

Berdasarkan analisis multivariat pada full model dengan menggunakan uji regresi logistic ganda menunjukkan tidak terdapat hubungan yang signifikan antara lingkar pinggang dengan kejadian hiperurisemia dengan $p=0,33$; OR=0,39; $95 \% \mathrm{Cl}=0,06-2,56$. Sama halnya dengan penelitian yang dilakukan pada tahun 2017 di Kelurahan Kedungmundu dengan jumlah sampel 46 orang yang menunjukkan hubungan yang signifikan antara lingkar pinggang dan hiperurisemia dengan $p=0,047^{10}$.

Pengukuran lingkar pinggang dapat menggambarkan penumpukan lemak tubuh bagian atas atau upper body obesity dan berhubungan dengan lemak pada intra abdominal (visceral fat). Komponen lemak viseral dan lemak subkutan memiliki risiko metabolik yang berbeda. Komponen lemak viseral secara metabolik aktif dan mengatur banyak adipositokin seperti leptin dan adiponektin, yang dikaitkan dengan resistensi insulin. Resistensi insulin atau hiperinsulinemia dapat meningkatkan reabsorpsi natrium dan asam urat pada tubulus ginjal, sehingga mengurangi eksresi asam urat dan menyebabkan hiperurisemia. Lemak Viseral memiliki hubungan yang lebih signifikan dengan kadar asam urat dibanding lemak subkutan hal ini disebabkan karena lemak viseral lebih berhubungan kuat dengan kadar insulin dibanding dengan lemak subkutan.

3. Hubungan Rasio Lingkar Pinggang Panggul dengan Hiperurisemia

Hasil analisis menggunakan fisher's exact tidak terdapat hubungan yang signifikan antara rasio lingkar pinggang panggul dengan kejadian hiperurisemia dengan $p=0,10 ; \mathrm{OR}=2,08$; $95 \% \mathrm{Cl}=0,17-24,61$. 
Berdasarkan analisis multivariat pada full model dengan menggunakan uji regresi logistic ganda menunjukkan tidak terdapat hubungan yang signifikan antara rasio lingkar pinggang panggul dengan kejadian hiperurisemia dengan $p=0,77$; $\mathrm{OR}=0,63 ; 95 \% \mathrm{Cl}=0,02-13,76$. Hal ini bertentangan dengan penelitian yang dilakukan di Puskesmas Tomposo pada tahun 2014 yang menunjukkan bahwa terdapat hubungan yang signifikan antara rasio lingkar pinggang panggul dengan kadar asam urat dengan $p=0,00$.

Dalam penelitian ini tidak menunjukkan adanya hubungan yang signifikan antara rasio lingkar pinggang panggul dengan hiperurisemia, karena rasio lingkar pinggang panggul berhubungan dengan indeks massa tubuh. Orang yang kurus tidak berarti mempunyai rasio lingkar pinggang panggul yang kecil dan begitu juga sebaliknya orang yang gemuk tidak berarti mempunyai rasio lingkar pinggang panggul besar. Sehingga variable rasio lingkar pinggang panggul bukan merupakan factor risiko hiperurisemia.

\section{Hubungan Tekanan Darah dengan Hiperurisemia}

Hasil analisis menggunakan chi square tidak terdapat hubungan yang signifikan antara tekanan darah dengan kejadian hiperurisemia dengan $p=0.35$; $\mathrm{OR}=1,78 ; 95 \% \mathrm{Cl}=0,52-6,08$. Penelitian ini sejalan dengan penelitian yang dilakukan dengan 36 sampel pada tahun 2013 di Cina menunjukkan bahwa tidak terdapat hubungan yang signifikan antara tekanan darah dan hiperurisemia dengan $p=0,11^{21}$. Berdasarkan analisis multivariat pada full model dengan menggunakan uji regresi logistic ganda menunjukkan tidak terdapat hubungan yang signifikan antara tekanan darah dengan kejadian hiperurisemia dengan $p=0,75 ; \mathrm{OR}=0,77$; $95 \% \mathrm{Cl}=0,15-3,86$. Lain halnya dengan penelitian yang dilakukan di Manado tahun 2015 dengan jumlah sampel 37 sampel menunjukkan bahwa terdapat hubungan yang signifikan antara tekanan darah dan asam urat dengan $p=0,022^{11}$. Berdasarkan penelitian ini sampel yang memiliki tekanan darah tinggi lebih sedikit daripada sampel yang memiliki tekanan darah normal. Sehingga dalam penelitian ini tidak terdapat hubungan yang signifikan antara tekanan darah dengan hiperurisemia.

\section{Hubungan Umur dengan Hiperurisemia}

Hasil analisis dengan menggunakan chi square tidak terdapat hubungan yang signifikan antara umur dengan hiperurisemia dengan $p=0,12$; $\mathrm{OR}=2,56 ; 95 \% \mathrm{Cl}=0,76-9,37$.

Berdasarkan analisis multivariat pada full model dengan menggunakan uji regresi logistic ganda menunjukkan tidak terdapat hubungan yang signifikan antara umur dengan kejadian hiperurisemia dengan $p=0,21 ; \mathrm{OR}=2,83 ; 95 \% \mathrm{Cl}=0,54-$ 14,79 . Lain halnya dengan penelitian yang dilakukan di Puskesmas Srimulyo, Triharjo, Sleman pada tahun 2012 dengan jumlah sampel sebanyak 75 orang menjelaskan bahwa terdapat hubungan umur dan hiperurisemia dengan $p=0,008^{21}$.

Secara teori semakin tua usia seseorang, maka beresiko memiliki kadar asam urat dalam darah yang lebih tinggi, proses penuaan menyebabkan terjadinya gangguan dalam pembentukan enzim akibat penurunan kualitas hormon. Dalam penelitian ini, pengambilan umur sampel antara kasus dengan kontrol tidak matching sehingga antara umur sampel kasus dengan kontrol berbeda.

\section{Hubungan Jenis Kelamin dengan Hiperurisemia}

Hasil analisis menggunakan chi square tidak terdapat hubungan yang signifikan antara jenis kelamin dengan hiperurisemia dengan $p=0,569$; OR=0,72 ; $95 \% \mathrm{Cl}=0,23-2,21$.

Berdasarkan analisis multivariat pada full model dengan menggunakan uji regresi logistic ganda menunjukkan tidak terdapat hubungan yang signifikan antara jenis kelamin dengan kejadian hiperurisemia dengan $p=0,74 ; \quad O R=1,34$; $95 \% \mathrm{Cl}=0,22-7,98$. Hal ini bertentangan dengan penelitian yang dilakukan di Puskesmas Paniki Bawah Kota Manado dengan 300 sampel menunjukkan bahwa ada hubungan yang signifikan antara jenis kelamin dan asam urat dengan $p=0,000^{22}$. Sampel pada penelitian kali ini baik sampel kasus maupun kontrol kebanyakan berjenis kelamin perempuan sehingga dengan pengambilan sampel yang kurang tepat variabel ini menjadi tidak bermakna. 
7. Hubungan Pendidikan dengan Hiperurisemia

Hasil analisis menggunakan regresi logstik tidak terdapat hubungan yang signifikan antara pendidikan dengan hiperurisemia dengan $p=0,33 ; \mathrm{OR}=2,38$; $95 \% \mathrm{Cl}=0,30-33,58$.

Berdasarkan analisis multivariat pada full model dengan menggunakan uji regresi logistic ganda menunjukkan tidak terdapat hubungan yang signifikan antara pendidikan dengan kejadian hiperurisemia dengan $p=0,45 ; \mathrm{OR}=3,17 ; 95 \% \mathrm{Cl}=0,15-$ 63,57 . Lain halnya dengan penelitian yang dilakukan dengan 36 sampel di Cina pada tahun 2013 menunjukkan bahwa ada hubungan yang signifikan antara pendidikan dengan hiperurisemia dengan $p=0,01^{21}$

Pada penelitian ini menunjukkan tidak terdapat hubungan yang signifikan antara pendidikan dengan hiperurisemia. Hal ini dikarenakan dalam penelitian ini prevalensi yang memiliki pendidikan menengah antara kasus dengan kontrol hampir sama yaitu masingmasing $68,0 \%$ dan $72,0 \%$. Sehingga variabel pendidikan bukan merupakan faktor risiko hiperurisemia.

\section{Hubungan Pekerjaan dengan} Hiperurisemia

Hasil analisis menggunakan regresi logistik tidak terdapat hubungan yang signifikan antara pekerjaan dengan hiperurisemia dengan $p=0,22 ; \mathrm{OR}=2,38$; $95 \% \mathrm{Cl}=0,58-9,64$.

Berdasarkan analisis multivariat pada full model dengan menggunakan uji regresi logistic ganda menunjukkan tidak terdapat hubungan yang signifikan antara pekerjaan dengan kejadian hiperurisemia dengan $p=0,33 ; \mathrm{OR}=2,39 ; 95 \% \mathrm{Cl}=0,40-$ 14,17 .

Pekerjaan tidak berpengaruh terhadap hiperurisemia, karena yang yang mempengaruhi kadar asam urat adalah aktivitas fisik. Sedangkan aktivitas fisik tidak hanya dilihat dari jenis pekerjaan, akan tetapi juga dilihat dari aktivitas lainnya, seperti olahraga dan aktivitas fisik selama dirumah. Sehingga variable ini tidak ada hubungannya dengan hiperurisemia.
9. Hubungan Pendapatan dengan Hiperurisemia

Hasil analisis menggunakan

fisher's exact tidak terdapat hubungan yang signifikan antara pendapatan dengan hiperurisemia dengan $p=0,60 ; \mathrm{OR}=3,27$ ; $95 \% \mathrm{Cl}=0,31$ - 33.83. Hal ini sejalan dengan penelitian yang dilakukan di Cina tahun 2010 dengan jumlah sampel 100 orang menunjukkan bahwa tidak terdapat hubungan yang signifikan antara pendapatan dan hiperurisemia dengan $p=0,32^{21}$

Berdasarkan analisis multivariat pada full model dengan menggunakan uji regresi logistic ganda menunjukkan tidak terdapat hubungan yang signifikan antara pendapatan dengan kejadian hiperurisemia dengan $p=0,64 ; \mathrm{OR}=0,53$; $95 \% \mathrm{Cl}=0,03-7,82$.

Dalam penelitian ini pendapatan tidak berhubungan signifikan dengan hiperurisemia, hal ini dikarenakan kebanyakan sampel memiliki tingkat pendapatan yang kurang dari pendapatan perkapita Kota Semarang.

\section{KESIMPULAN}

Kesimpulan dari 9 faktor yang di analaisis hanya linkar pinggang yang beresiko terhadap timbulnya hiperurisemia, sedangkan faktor lain seperti ; IMT, RLPP, tekanan darah, umur, jenis kelamin, pendidikan, pekerjaan dan pendapatan tidak sebagai faktor resiko timbulnya hiperurisemia.

\section{SARAN}

Bagi peneliti perlu dilakukan penelitian sejenis dengan desain penelitian lain, yaitu dengan dilakukan matching antara jenis kelamin dan usia, jumlah sampel yang lebih besar dan cakupan yang lebih luas, sehingga dapat menjadi pembanding.

\section{DAFTAR PUSTAKA}

1. Kemenkes RI. Buletin Jendela Data dan Informasi Kesehatan. Jakarta: Kementerian Kesehatan RI; 2012.

2. Damayanti D. Sembuh Total Diabetes Asam Urat Hipertensi Tanpa Obat. Yogyakarta: Pinang Merah Publisher; 2013. 73-122 p.

3. Smith E, March L. Global Prevalence of Hyperuricemia: A Systematic Review of Population-Based Epidemiological Studies. ACR Meet Abstr. 2015;

4. Krisnatuti D. Diet Sehat untuk Penderita Asam Urat. Jakarta: Penebar Swadaya; 2008.

5. Carran EL. Fructose Intake from Sugar- 
Sweetened Beverages and Acute Plasma Uric Acid Production. 2015;

6. Almatsier S. Prinsip Dasar Ilmu Gizi. Jakarta: Gramedia Pustaka Utama; 2003.

7. Mulyasari A. Faktor Asupan Zat Gizi Yang Berhubungan Dengan Kadar Asam Urat Darah Wanita Postmenopause. Universitas Diponegoro; 2015.

8. Asmak N. Hubungan Asupan Bahan Makanan Sumber Purin, Vitamin C, dan Cairan dengan Kadar Asam Urat pada Pasien Hiperurisemia Rawat Jalan di Rumah Sakit Roemani Muhammadiyah Semarang. 2017;

9. Hariadi, Suprayitno E, Asnindari LN. Hubungan Indeks Massa Tubuh Dengan Kadar Asam Urat Di Dusun Niten Nogotirto Gamping Sleman Yogyakarta. 2016;10.

10. Rizki MU, Probosari E, Nissa C. Hubungan Lingkar Pinggang, Rasio Lingkar Pinggang Terhadap Tinggi Badan Dan Indeks Massa Tubuh Dengan Kadar Asam Urat Wanita Usia 45-55 Tahun. J Nutr Coll. 2017;6:358-61.

11. Mansur SN, Watania FE, Surachmanto E. Hubungan Antara Kadar Asam Urat dengan Tekanan Darah pada Mahasiswa Pria Obesitas Sentral Fakultas Kedokteran Universitas Sam Ratulagi Manado. Exp Clin Cardiol. 2015;3(1):381-7.

12. Rini. Hubungan Jenis Kelamin Dan Asupan Purin Dengan Kadar Asam Urat Pada Lansia Di Posyandu Peduli Insani Mendungan Desa Pabelan Kecamatan Kartasura Kabupaten Sukoharjo. Skripsi. 2017;

13. Liu H, Zhang X-M, Wang Y-L, Liu B-C. Prevalence of Hyperuricemia Among Chinese Adults: A National Cross-Sectional Survey Using Multistage, Stratified Sampling. J Nephrol. 2014;27(6):653-8.

14. Ariani RD. Hubungan Tingkat Pengetahuan Penderita Asam Urat Dengan Kepatuhan Diet Rendah Purin Di Gawanan Timur Kecamatan Colomadu Karanganyar. Skripsi. 2014;1-59.

15. Azwar S. Sikap Manusia, Teori Dan Pengukurannya. Yogyakarta: Pustaka Pelajar; 2012.

16. Lanny Lingga P. Bebas Penyakit Asam Urat Tanpa Obat. DP T, editor. Jakarta: PT AgroMedia Pustaka; 2012. 75-76 p.

17. Montol AB. Konsumsi Minuman Beralkohol dan Kadar Asam Urat pada Pria Dewasa di Kelurahan Koya Kecamatan Tondano Selatan Kabupaten Minahasa. Gizido. 2014;6(1):6-7.

18. Kumalasari TS, Saryono, Punawan I. Hubungan Indeks Massa Tubuh Dengan Kadar Asam Urat Darah Pada Penduduk Desa Banjaranyar Kecamatan Sokaraja Kabupaten Banyumas. J Keperawatan Soedirman. 2009;
19. Qiu L, Cheng X, Wu J, Liu J, Xu T, Ding H, et al. Prevalence of Hyperuricemia and Its Related Risk Factors in Healthy Adults from Northern and Northeastern Chinese provinces. 2013;(5).

20. Wulandari D. Hubungan Lingkar Pinggang Dan Indeks Massa Tubuh Dengan Kadar Asam Urat Wanita Usia Di Atas 50 Tahun. Skripsi. 2015;117.

21. Villegas $R$, Xiang $Y-B$, Cai $Q$, Fazio $S$, Linton $M$, $\mathrm{Li} H$, et al. Prevalence snd Determinants of Hyperuricemia in Middle-Aged, Urban Chinese Men. Metab Syndr Relat Disord. 2010;8.

22. Jilly Priskila Lioso, Ricky C. Sondakh BTR. Hubungan Antara Umur, Jenis Kelamin Dan Indeks Massa Tubuh Dengan Kadar Asam Urat Darahpada Masyarakat Yang Datang Berkunjung Di Puskesmas Paniki Bawah Kota Manado. 2015;5. 